\title{
Effects of an Augmented Reality Library Orientation on Anxiety and Self-Efficacy: An Exploratory Study
}

\section{Samantha Kannegiser}

\begin{abstract}
Academic libraries use scavenger hunt library orientations to engage students and teach them about the library. Libraries are also starting to use augmented reality (AR) technology in orientations, instruction, and programming. Some libraries have tried augmented reality scavenger hunts for freshman library orientations, but studies have not been done to compare the traditional and AR orientations. This exploratory, quasi-experimental study investigates if the AR library orientation impacts freshman undergraduates' perceptions of the library as measured by students' anxiety and confidence levels. Two groups of first-time, first-year undergraduate students participated in a library orientation in Summer 2019. One received the traditional scavenger hunt model, and another experienced an augmented reality version of the scavenger hunt. Both groups took a pre-orientation survey to determine their comfort with the libraries and librarians in general, and then a post-orientation questionnaire to determine any change in perception of libraries and librarians as well as their satisfaction with the orientation experience. By comparing pre- and post-survey results from both sets of students, this study determined that while both orientations had a positive impact on students' perceptions of the library, the AR orientation had a significant impact on students' perceptions of librarians' desire to help them.
\end{abstract}

\section{Introduction}

Librarians' multifaceted efforts to connect with students often focus on reducing students' anxieties and building their feelings of self-efficacy. One of the first experiences students have with the academic library is during orientation, creating an ideal opportunity to reduce students' feelings of library anxiety, a well-documented phenomenon of students feeling intimidated by the library building, staff, and resources. Orientations can build students' feelings of confidence in navigating and using the library and reduce their feelings of discomfort in asking for help. By reducing anxiety and bolstering students' beliefs in their abilities, librarians use orientations as the first step in shaping information literate students.

New approaches to library orientation are common as new ideas and technologies emerge. One such technology, augmented reality (AR), is increasingly used in library and educational

\footnotetext{
*Samantha Kannegiser is Student Success Librarian, Library Faculty in Paul Robeson Library at Rutgers University-Camden; email: sck77@libraries.rutgers.edu. (2021 Samantha Kannegiser, Attribution-NonCommercial (https://creativecommons.org/licenses/by-nc/4.0/) CC BY-NC.
} 
settings. AR is an interactive technology that overlays virtual information, in such forms as videos, audio, and 3-D models, onto a real-world environment. Participants move through the augmented physical environment and experience the overlaid information through a device such as a smartphone or a tablet. The physical and virtual information work together to create an enriched learning experience. As user-friendly options for implementing AR grew, libraries adopted the technology for library initiatives, such as library orientations.

Researchers in psychology and education have studied the effect of augmented reality on anxiety and self-efficacy. This study aims to expand on this research by investigating the effect of an augmented reality library orientation on students' feelings of library anxiety and self-efficacy through self-reported measures of comfort and confidence with the library building, staff, and usage.

\section{Literature Review}

Library anxiety, a theory introduced by Constance Mellon in 1986, posits that students experience fear toward the library regarding its perceived large size, their uncertainty about where things are located within the library, how to begin using the library, or what to do to use the library. ${ }^{1}$ These feelings are coupled with a belief that they are alone in their inability to use the library and that their incompetence is shameful and needs to be hidden. ${ }^{2}$ In 1992 , Sharon L. Bostick developed the Library Anxiety Scale (LAS) and narrowed the factors encompassed by library anxiety to barriers with staff, affective barriers, comfort with the library, knowledge of the library, and mechanical barriers. ${ }^{3}$ Students who experience library anxiety are at a disadvantage, as anxiety can affect their behavior, which can negatively affect their learning. ${ }^{4}$ There is a positive correlation between library use and student success; students who use their library have higher GPAs, are retained longer, are in good academic standing, and are engaged academically. ${ }^{5}$ Library anxiety, however, can have a negative academic impact on students who may procrastinate assignments or submit subpar papers. ${ }^{6}$ Unsurprisingly, new and early undergraduates report higher levels of library anxiety. ${ }^{7}$

Anxiety, and specifically academic anxieties, have been studied in relation to selfefficacy. Self-efficacy refers to an individual's belief that they have the abilities required to produce a desired outcome. ${ }^{8}$ This belief is not necessarily correlated with one's actual abilities; instead, it refers to one's feelings of confidence that they can produce specific results. The strength of this belief can determine the initial amount of effort they will put forth to complete a task and their level of perseverance in completing the task. ${ }^{9}$ Self-efficacy beliefs are influenced by one's previous experience performing comparable tasks, vicarious experiences watching others model performing the task, verbal persuasion, or encouragement, and physiological states, or one's interpretation of their emotional or physical reactions to completing a task. ${ }^{10}$ One's emotional or physical responses can be manifestations of anxiety; if one feels anxious approaching a situation, it can affect their confidence in their ability to successfully navigate that situation. Researchers studying the relationship between selfefficacy and a range of academic anxieties, such as with writing, math, and testing, find that students who report higher levels of anxiety toward a task tend to have lower self-efficacy beliefs about that task. ${ }^{11}$

In libraries, researchers have investigated the relationship between library instruction and library use and self-efficacy. Library instruction was shown to significantly increase students' feelings of self-efficacy, and library use was correlated with feelings of high self-efficacy. ${ }^{12}$ 
The majority of these studies correlate students' self-reported feelings of efficacy with their experiences with the library (in other words, the number of instruction sessions or frequency of library visits) but don't necessarily compare the students' self-efficacy with efficacy or their ability to actually perform well on library-related tasks. Gross and Latham, however, studied the relationship between students' estimates of their skill level and their actual skill level and found that "students who demonstrate low-level skills hold inflated views of their abilities" regarding information literacy. ${ }^{13}$ Gross and Latham did not find a significant relationship between students' scores on an information literacy test and their scores on the library anxiety scale. ${ }^{14}$ The only correlation they did find was within the library anxiety subscale of "knowledge of the library"; students with higher information literacy scores felt more confident in their knowledge about the library. ${ }^{15}$

A small number of studies investigate the effect of augmented reality (AR) in a learning environment on students' self-efficacy. Graduate students practiced leading professional learning communities with the use of an immersive classroom simulation and reported an increase in self-efficacy ratings, as measured by feelings of confidence doing certain tasks, following the simulation. ${ }^{16}$ The researchers found that two forms of immersive learning had similar effects: mastery experiences and vicarious learning. Participants who were actively practicing in the immersive environment reported increased self-efficacy as well as participants who watched the immersion passively. ${ }^{17}$

Augmented reality had a different effect on self-efficacy in a vocational educational setting; students completed tasks faster when using AR than when not, but their self-efficacy did not increase a significant amount after using AR..$^{18}$ The researchers hypothesize that this is due to insufficient time spent using the AR as "self-efficacy is a concept which develops in time and with experiences." ${ }^{19}$ However, the vocational students used AR over a six-week period, whereas the graduate students had one 10-minute immersive AR experience and still showed increased self-efficacy. ${ }^{20}$ The effect of augmented reality on self-efficacy is inconclusive and requires more research. Other studies have shown other benefits of using augmented reality in education, such as improving learning gains and increasing student motivation. ${ }^{21}$ Researchers in psychology have investigated the effect of AR as a treatment for diagnosed anxiety disorders, namely a variety of phobias, but studies have not been done on the effect of AR on academic anxieties, such as library anxiety. ${ }^{22}$

Although still considered an emerging technology, augmented reality use in libraries is widespread and diverse. Libraries are using AR for collection discovery, library navigation, exhibits, instruction, and orientations. In Taiwan, public librarians used AR to make their book search process more intuitive and self-directed..$^{23}$ At Emporia State University, AR was used to market Banned Books Week events and to create information literacy assignments; at Towson University it was used to create immersive exhibits. ${ }^{24}$ At The Dolly and Homer Hand Law Library, students can opt into an AR Scavenger Hunt for a chance to win prizes. ${ }^{25}$ Chen and Tsai found that elementary-age Taiwanese students benefited equally from AR and inperson library instruction, particularly when instruction was "associated with application and comprehension." ${ }^{26} \mathrm{AR}$ is being used for library orientations as well, and participants report generally positive responses in terms of their enjoyment of the activity and usefulness of the orientation. ${ }^{27}$ Common complaints are generally limited to the technology platform itself, which some users found "touchy" or confusing." ${ }^{28}$ Overall, augmented reality is proving to be a promising tool in education and librarianship for engaging and teaching students. 
By merging augmented reality with its scavenger hunt library orientation, the Paul Robeson Library at Rutgers University-Camden hoped to effectively welcome new undergraduate students to their library while also building their confidence and reducing feelings of library anxiety. The orientation consists of librarians guiding students through the scavenger hunt virtually via prerecorded videos that are overlaid on physical library spaces, thereby minimizing the time librarians must actively participate in orientation activities. These videos also give librarians more control over the information relayed to students about each stop on the hunt versus the traditional scavenger hunt model, which can make the experience more consistent. Rather than ticking off boxes or jotting down answers to the scavenger hunt clues, the students are required to watch short videos of librarians explaining the space or highlighting a service before working together to unravel clues and discover new parts of the library, making the experience more meaningful. These unique characteristics of an AR scavenger hunt create a wholly different learning experience than that with a traditional scavenger hunt orientation, which is frequently used to decrease students' library anxiety and increase their confidence using the library. Often these orientations result in students reporting decreased levels of anxiety and increased levels of comfort. ${ }^{29}$ There are fewer studies that compare students' perceptions of the library after completing different orientation formats (such as a traditional scavenger hunt to a technology-enhanced scavenger hunt), with the exception of a 2003 study comparing perceptions of new undergraduate students taking a traditional library tour to those doing a self-paced scavenger hunt, but the authors found that the type of orientation taken did not dramatically affect students' attitudes toward the library. ${ }^{30}$

By comparing students taking a traditional scavenger hunt orientation to students taking an augmented reality version of the same orientation, this study aims to answer the following research questions:

1. Do students who participate in the augmented reality library orientation report lower levels of library anxiety than those who participate in the traditional library orientation?

2. Do students who participate in the augmented reality library orientation report higher levels of confidence using and navigating the library than those who participate in the traditional library orientation?

3. Do students who participate in the augmented reality library orientation report a higher level of satisfaction with the activity than those who participate in the traditional library orientation?

\section{Methods}

This study employs a quasi-experimental design to identify the causal relationship between the type of orientation taken and students' anxiety toward the library, confidence using the library, and satisfaction with the orientation experience. A quasi-experimental design differs from experimental design in that random sampling is not used.

Rutgers University-Camden participates in two state-funded programs called the Educational Opportunity Fund (EOF) and $\mathrm{TRiO}$, and, as a requirement of these programs, students participate in a weeks-long summer workshop to orient them to the campus. The library orientation is a part of these activities, so these groups were chosen to be the studied population. These programs help fund tuition for first-generation students and economically 
disadvantaged students. First-generation students report feelings of library anxiety similar to their non-FGS peers, but they are also less likely to use libraries, with the exception of online reference services. ${ }^{31}$ Like their non-FGS peers, these students have a low awareness of library services, find the atmosphere of the academic library overwhelming compared to their high school or public libraries, and feel that library resources are hard to find. ${ }^{32}$ These are characteristics of library anxiety specifically tied to the library anxiety scale factors of comfort with the library and knowledge of the library.

The EOF-program students were chosen to participate in the augmented reality orientation (the treatment group), and the TRiO-program students were chosen for the traditional library orientation (the control group). Random sampling was not possible due to class sizes and scheduling constraints - everyone from a single class needed to take the same orientation on the same date.

The control group completed a traditional, self-paced, library orientation scavenger hunt. Clues and questions were administered via a Survey Monkey survey that students accessed on their personal devices or library iPads (see appendix A). In small groups, students followed the clues and answered the questions by walking throughout the building, asking questions, reading signs, and working together.

The treatment group completed a self-paced augmented reality library orientation using the library iPads. This group completed the activity by viewing an augmented reality flyer at each scavenger hunt stop, which guided them through the activity by informing them of library resources and giving hints for the next orientation stops (see appendix B). By scanning the flyers with the iPads, students would trigger the augmented reality component to play on top of the flyer, giving the illusion of a flyer "coming to life." Each flyer held a clue that students deciphered together to move to the next stop on the orientation. Both the control and treatment groups received the same clues but in different formats (the control group saw clues on the SurveyMonkey survey and the treatment group saw clues on the augmented reality flyer). All augmented reality components of the activity were implemented using Zappar, a subscription platform for augmented reality design.

Pre- and post-orientation surveys were administered to the control and treatment groups immediately before and immediately after the orientations. Questionnaires were administered online in a computer classroom. Students entered their initials on both surveys to enable matching of pre- and post-orientation answers. Once surveys were matched, the identifying data was erased. The control and treatment groups had 25 students each, but not every student correctly filled out their initials on both pre- and post-surveys to enable matching. The matched, usable surveys for each group totaled 21 for the treatment group and 22 for the control group.

The surveys were used to assess participants' perceptions of the library and satisfaction level with the orientation experience. To measure students' perceptions of the library, five survey questions were modified from Bostick's Library Anxiety Scale (1992). This instrument was modified for wording and length because the participants were likely to have little to no experience with the library before this orientation and a short instrument was more likely to be completed in full. The five survey questions focused on feelings of anxiety related to four of Bostick's five factors: barriers with staff, affective barriers, comfort with the library, and knowledge of the library (see appendices $C$ and D). These questions appeared on both the pre- and post-orientation surveys. Also on the post-orientation survey were two additional 
questions related to the students' specific university library; these questions measured student confidence using their university library after being introduced to the building, people, and services via the orientation (see appendix D).

Questions measuring students' enjoyment of the experience, eagerness to return to the library, and likelihood to recommend the university library was asked to determine students' satisfaction with the orientation experience (see appendix D). These questions for measuring satisfaction were modified from Marino's survey questions for measuring student satisfaction with an instruction session. ${ }^{33}$ All survey questions were scored using a forced-choice 4-point interval Likert scale with anchored first and last numbers.

\section{Findings}

Descriptive statistics were used to determine any top-level trends in the data for both types of orientations. Both the control and treatment groups rated the post-orientation anxiety questions similarly (see figures 1 and 2).
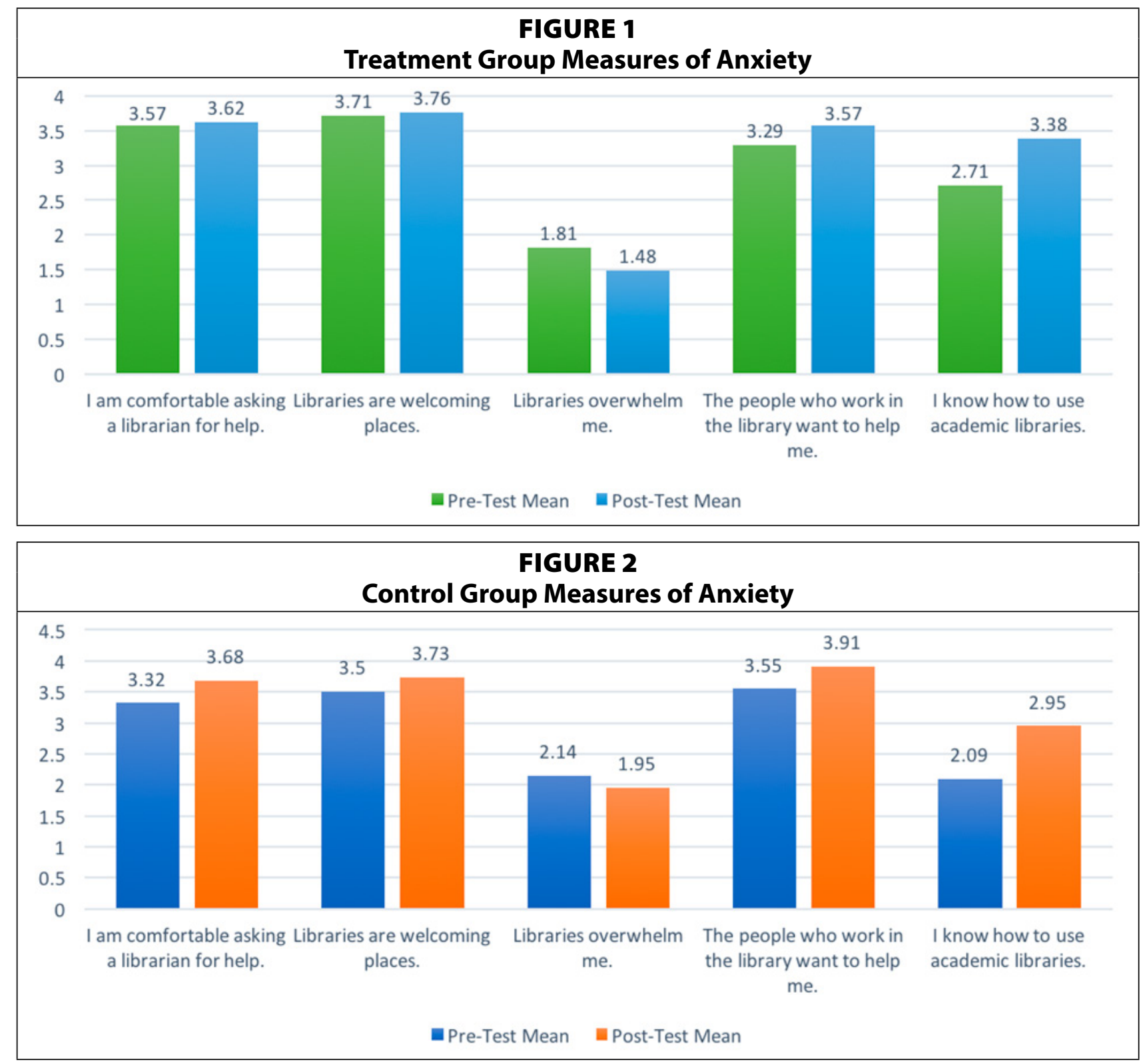
The only notable difference was for this statement: "I know how to use academic libraries." The treatment group rated this an average of 3.38 after taking the orientation (see figure 1). The control group most rated this an average of 2.95 after taking the orientation (see figure 2). Both the control and treatment groups rated the post-orientation confidence questions similarly as well.

There was a slight difference when rating the statement: "I can easily find my way around the Rutgers University-Camden library," with the treatment group rating an average of 3.43 and the control group rating an average of 3 (see figure 3 ).
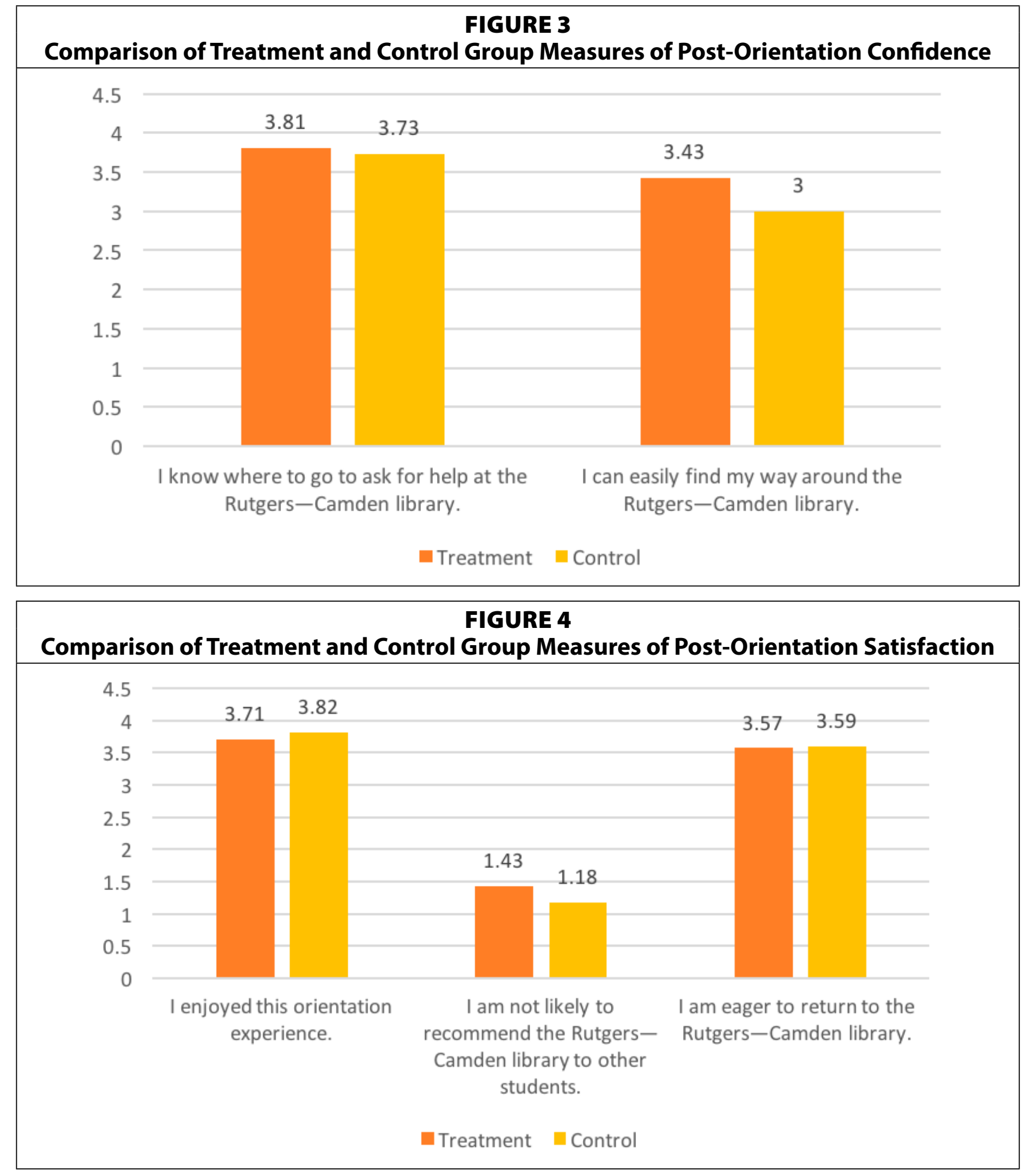
In terms of satisfaction with the orientation experience, both the treatment and control groups rated the orientation similarly (see figure 4). The highest average ratings were for the statement "I enjoyed this orientation experience," with an average treatment group rating of 3.71 and control group rating of 3.82. Slightly more students in the control group strongly disagreed with the statement "I am not likely to recommend the Rutgers-Camden library to other students," with a lower average rating of 1.18 versus the treatment group's average rating of 1.43. Regarding their eagerness to return to the campus library, the treatment and control groups rated an average of 3.57 and 3.59 respectively.

Inferential statistics were used to determine any statistically significant impact of the orientations. Paired sample t-tests were performed for the matched pre- and post-orientation questions (see appendices A and B, questions 1-5) within each group to determine if the respective orientations had an impact on students' perceptions of the library. These tests measure if either orientation had a significant effect on students' anxiety or confidence toward the library. Any question that was determined to have a significant impact was then measured for effect size using Cohen's d test; a larger effect size shows a stronger relationship between two variables (for example, type of orientation taken and level of anxiety felt toward librarians). Independent sample t-tests were performed on the post-orientation questions (see appendix $B$, questions 6-10) means for the control and treatment groups to determine if the augmented reality had a significant impact on students' confidence using their university library and satisfaction with the orientation experience as compared to the control group.

\section{Effect of Orientation on Students' Anxiety and Confidence}

Within the control group, the traditional orientation was found to have a statistically significant impact on the following statements (see table 1):

- I am comfortable asking a librarian for help. $(p=.002)$

- The people who work in the library want to help me. $(p=.017)$

- I know how to use academic libraries. $(p=.002)$

\begin{tabular}{|c|c|c|c|c|c|c|c|c|c|}
\hline \multicolumn{10}{|c|}{$\begin{array}{r}\text { TABLE } 1 \\
\text { PSPP Output for Control Group Paired t- }\end{array}$} \\
\hline \multirow{3}{*}{ 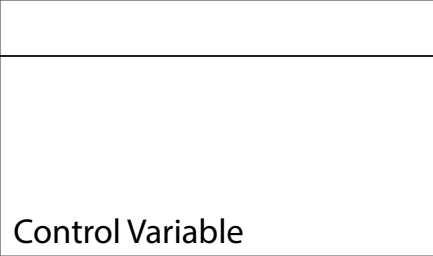 } & \multicolumn{5}{|c|}{ Paired Differences } & \multirow[b]{3}{*}{$\mathrm{t}$} & \multirow[b]{3}{*}{$\mathrm{df}$} & \multirow{3}{*}{$\begin{array}{c}\text { Sig. } \\
\text { (2-tailed) }\end{array}$} & \multirow[b]{3}{*}{ Cohen's d } \\
\hline & \multirow[b]{2}{*}{ Mean } & \multirow{2}{*}{$\begin{array}{c}\text { Std. } \\
\text { Deviation }\end{array}$} & \multirow{2}{*}{$\begin{array}{l}\text { Std. Error } \\
\text { Mean }\end{array}$} & \multicolumn{2}{|c|}{\begin{tabular}{|c|}
$95 \%$ Confidence \\
Interval of the \\
Difference \\
\end{tabular}} & & & & \\
\hline & & & & Lower & Upper & & & & \\
\hline $\begin{array}{l}\text { I am comfortable asking a } \\
\text { librarian for help. }\end{array}$ & -0.36 & 0.49 & 0.1 & -0.58 & -0.15 & -3.46 & 21 & 0.002 & 0.542689297 \\
\hline $\begin{array}{l}\text { Libraries are welcoming } \\
\text { Places. }\end{array}$ & -0.23 & 0.61 & 0.13 & -0.5 & 0.04 & -1.74 & 21 & 0.096 & 0.342863958 \\
\hline Libraries overwhelm me. & 0.18 & 0.91 & 0.19 & -0.22 & 0.58 & 0.94 & 21 & 0.358 & -0.194869197 \\
\hline $\begin{array}{l}\text { The people who work in } \\
\text { the library want to help } \\
\text { me. }\end{array}$ & -0.36 & 0.66 & 0.14 & -0.66 & -0.07 & -2.59 & 21 & 0.017 & 0.785117659 \\
\hline $\begin{array}{l}\text { I know how to use } \\
\text { academic libraries. }\end{array}$ & -0.86 & 1.13 & 0.24 & -1.36 & -0.36 & -3.6 & 21 & 0.002 & 0.994070255 \\
\hline
\end{tabular}




\begin{tabular}{|c|c|c|c|c|c|c|c|c|c|}
\hline \multirow[b]{4}{*}{ Treatment Variable } & or Trea & tment G & $\begin{array}{r}\text { TABL } \\
\text { oup Pair }\end{array}$ & $\begin{array}{l}\text { E } 2 \\
\text { ed } t-T e\end{array}$ & ts with & \multirow[b]{4}{*}{$\mathrm{t}$} & \multirow[b]{4}{*}{ df } & \multirow{4}{*}{$\begin{array}{c}\text { Sig. } \\
\text { (2-tailed) }\end{array}$} & \multirow[b]{4}{*}{ Cohen's d } \\
\hline & & Paire & d Differen & ces & & & & & \\
\hline & \multirow[b]{2}{*}{ Mean } & \multirow{2}{*}{$\begin{array}{c}\text { Std } \\
\text { Deviation }\end{array}$} & \multirow{2}{*}{$\begin{array}{l}\text { Std. Error } \\
\text { Mean }\end{array}$} & \multicolumn{2}{|c|}{\begin{tabular}{|c|}
$\begin{array}{c}95 \% \text { Confidence } \\
\text { Interval of the } \\
\text { Difference }\end{array}$ \\
\end{tabular}} & & & & \\
\hline & & & & Lower & Upper & & & & \\
\hline $\begin{array}{l}\text { I am comfortable asking a } \\
\text { Librarian for help. }\end{array}$ & -0.05 & 0.38 & 0.08 & -0.22 & 0.13 & -0.57 & 20 & 0.576 & 0.086206897 \\
\hline $\begin{array}{l}\text { Libraries are welcoming } \\
\text { places. }\end{array}$ & -0.05 & 0.5 & 0.11 & -0.27 & 0.18 & -0.44 & 20 & 0.666 & 0.1017025 \\
\hline Libraries overwhelm me. & 0.33 & 0.91 & 0.2 & -0.08 & 0.75 & 1.67 & 20 & 0.11 & -0.388235294 \\
\hline $\begin{array}{l}\text { The people who work in the } \\
\text { Library want to help me. }\end{array}$ & -0.29 & 0.56 & 0.12 & -0.54 & -0.03 & -2.34 & 20 & 0.03 & 0.462415527 \\
\hline $\begin{array}{l}\text { I know how to use } \\
\text { academic libraries. }\end{array}$ & -0.67 & 0.97 & 0.21 & -1.11 & -0.23 & -3.16 & 20 & 0.005 & 0.752737944 \\
\hline
\end{tabular}

The size of the impact, as measured by Cohen's $d$, was only large for the last two statements:

- The people who work in the library want to help me. $(\mathrm{d}=.785)$

- I know how to use academic libraries. $(\mathrm{d}=.994)$

Within the treatment group, the augmented reality orientation was found to have a statistically significant impact on the following statements (see table 2):

- The people who work in the library want to help me. $(\mathrm{p}=.030)$

- I know how to use academic libraries. $(\mathrm{p}=.005)$

The size of the impact, as measured by Cohen's $d$, was only large for the following statement:

- I know how to use academic libraries. $(\mathrm{d}=.753)$

\section{Comparing the Control and Treatment Groups}

The augmented reality orientation was shown to have a statistically significant impact on the following statements measuring library anxiety, as compared to a traditional orientation (see table 3):

\begin{tabular}{|c|c|c|c|c|c|c|c|c|c|c|}
\hline & SPSS & utput I & ndepe & $\begin{array}{r}\text { TA } \\
\text { enden }\end{array}$ & $\begin{array}{l}\text { BLE } 3 \\
\text { Samp }\end{array}$ & es Test fo & r Questio & n 4 & & \\
\hline SPSS output & Independent Sar & ples Test & for Qu & iestion & 4: "The $\mathrm{p}$ & eople whc & work in th & e library wa & nt to he & me." \\
\hline & & $\begin{array}{l}\text { Levene } \\
\text { for Equ } \\
\text { of Varia }\end{array}$ & $\begin{array}{l}\text { s Test } \\
\text { ality } \\
\text { nces }\end{array}$ & t-test $f$ & or Equa & ity of Mea & & & & \\
\hline & & & & & & Siq. & Mean & Std. Error & $\begin{array}{r}95 \% \text { Cor } \\
\text { Interva } \\
\text { Diffe }\end{array}$ & $\begin{array}{l}\text { idence } \\
\text { of the } \\
\text { ince }\end{array}$ \\
\hline & & $\mathrm{F}$ & Sig. & $\mathrm{t}$ & $\mathrm{df}$ & (2-tailed) & Difference & Difference & Lower & Upper \\
\hline ת & $\begin{array}{l}\text { Equal variances } \\
\text { assumed }\end{array}$ & 24.021 & .000 & 2.367 & 41 & .023 & .338 & .143 & .050 & .626 \\
\hline берепाиели & $\begin{array}{l}\text { Equal variances } \\
\text { not assumed }\end{array}$ & & & 2.333 & 28.856 & .027 & .338 & .145 & .042 & .634 \\
\hline
\end{tabular}


- The people who work in the library want to help me $(p=.027)$. The effect of augmented reality on this factor was large $(\mathrm{d}=.742)$.

Augmented reality had no significant impact on measures of students' self-efficacy. Both the control and treatment groups reported feeling confident navigating and using the library. The control group had a slightly lower mean rating for the statement "I can easily find my way around the Rutgers University-Camden library" (see figure 3). The reasons for this are discussed in the next section.

\section{Satisfaction with the Orientation Experience}

Augmented reality had no impact on students' satisfaction with the orientation experience, as measured by the last three questions on the post-orientation survey. Both groups reported high levels of satisfaction regardless of orientation format.

\section{Discussion}

The augmented reality outperformed the traditional orientation in only one area: students' perception that librarians and staff want to help them. This variable is directly related to the library anxiety factor barriers with staff. New students will continue to be exposed to the other aspects of the library such as the building and resources throughout their first semester through library instruction, but convincing them that librarians and staff desire to help them is an encouraging impact of the AR. Through library instruction, librarians can reduce students' anxiety related to building and resource navigation and that instruction may be more impactful if students are already convinced that the librarians are truly supportive of students. Additionally, the effect of AR on students' perception of librarians is a promising result when considering the sustainability of the augmented reality orientation-students can take the orientation at any time and hear a consistent message from librarians without requiring librarians to physically take part in each orientation. The technology allows librarians and library staff to connect with students on a grander scale than if they were to conduct orientations in person, which would be limited by availability.

Although the impact of AR on this facet of library anxiety is worthwhile, it is still the only variable studied that was affected by the technology. There are some possible reasons for this finding. One, this study was exploratory and small in nature. A larger study with more students may uncover a bigger impact on other aspects of library anxiety and self-efficacy. Two, this study employed one form of augmented-reality videos superimposed on flyers to create the perception of an image "coming to life." Augmented reality can take many other forms, and a more complex and immersive form may have had a different impact on students.

Both orientations had a positive and significant impact on measures of students' anxiety toward the library and their confidence using the library. For factors in which the orientation did not have a statistically significant impact, students in both groups still overwhelmingly reported feeling more comfortable and confident in the library and with librarians. This is suggestive of the effectiveness of library orientations that are active, student-led, and gamified, as both orientations shared these characteristics regardless of the technology used and is supported by the fact that both groups reported high levels of satisfaction with their orientation.

For the one confidence measure for which the control group had a slightly lower mean than the treatment group: "I can easily find my way around the Rutgers University-Camden library" (see figure 3), the difference is potentially explained due to a portion of the library 
being closed off for maintenance during the control group's orientation. This didn't affect the content delivered to students, but they were told that they could not explore one area of the library during the orientation. This hindrance could be a reason for students in the control group to feel slightly less confident navigating the library since they knew they had not seen the entirety of the building during the orientation.

\section{Conclusion}

This study showed that augmented reality does as good a job at orienting students as other active learning exercises, but a significantly better job improving students' perception that librarians want to help them. This variable is directly related to the "Barriers with Staff" subscale of the Library Anxiety Scale and shows that AR that showcases librarians and staff can be impactful in reducing students' feelings of anxiety toward librarians and library staff. Although only one factor out of many studied here, this is an important result. Reducing students' anxiety toward librarians is an important step toward meaningfully engaging with students and affecting their academic success, and augmented reality is an innovative way of doing so.

Although students' confidence levels were not greatly impacted by either orientation, both groups reported feeling confident using and navigating the library after the orientations. This does not affirm the superiority of AR orientations, but it does suggest that active and gamified orientations are successful in building students' confidence. This is also supported by the high satisfaction ratings reported by both groups after the orientations.

The augmented reality orientation is a worthwhile endeavor for any academic library interested in creating an active, student-centered experience that still incorporates the librarians' presence and expertise. This orientation is particularly useful because it is sustainable and scalable. Librarians can record themselves giving information or demonstrating a process and use that recording as part of the AR content, allowing them to reach more students than if they were limited to only orientations for which they could be present. Transforming the recordings into AR content is a powerful way to disseminate this information: students are not watching an orientation video remotely; instead, they are receiving the information while in the relevant environment. An augmented reality flyer placed on the reference desk "comes alive," showing the student the librarian at the reference desk relaying necessary information. In this way, an AR orientation can seamlessly merge an in-person, librarian-led tour with a traditional, student-directed scavenger hunt orientation while avoiding the limitations of either format.

\section{Limitations and Future Research}

This study was small and exploratory in nature. Random sampling was not possible due to class schedules. Larger studies employing random sampling are necessary.

AR can be intimidating to adopt as it is still "emerging" and there are overwhelming options for its implementation. There are some challenges to using AR. There are documented side effects to using mixed reality, particularly head-mounted virtual reality, such as nausea and dizziness. ${ }^{34}$ There are also audio and visual components to mixed reality, which can prohibit visual and hearing-impaired users from getting the full experience. However, virtual and augmented reality can bring otherwise inaccessible environments to users by creating an immersive experience. ${ }^{35}$ There are options for using AR that meet a variety of skill levels 
and budgets so prior experience and cost are usually not barriers to adoption, but most AR providers are proprietary companies and the AR objects created on one platform are usually not accessible via another. This can be frustrating for users having to download multiple applications. Those working in libraries should weigh the challenges and advantages of using AR to determine the appropriate course of action for their needs.

Lasting changes in self-efficacy beliefs can be achieved by scaffolding: introducing someone to a task so that they can develop their abilities and then gradually removing assistance and giving opportunities for them to act independently so that feelings of self-efficacy are strengthened. ${ }^{36}$ Since the augmented reality orientation is the first step of a multistep process of guiding students toward information-literate behaviors, part of which are confidently using the library and its resources, it would be interesting to study the effects of augmented reality on self-efficacy beliefs across the other steps in this process, such as library instruction and programming. 


\section{APPENDIX A. Screenshot of Scavenger Hunt Given to Control Group}

Library Orientation Scavenger Hunt

Library Orientation Scavenger Hunt

Welcome to the library scavenger hunt!

Your group is tasked with hunting for information throughout the library. Use the clues below and the accompanying map of the library to travel throughout the library finding information to answer the following questions.

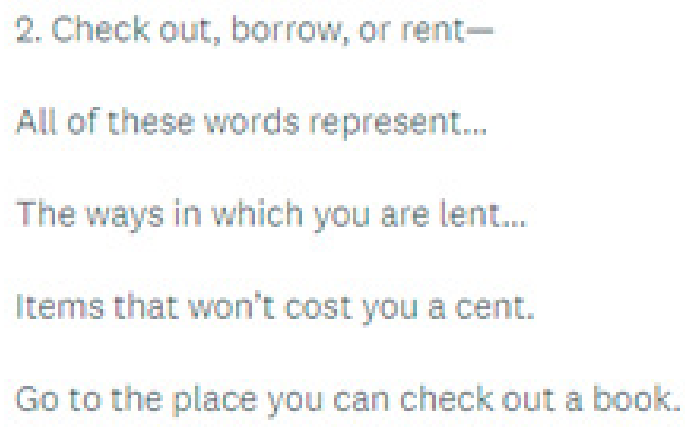




\section{APPENDIX B. Augmented Reality Flyer}

Anyone can download the Zappar mobile application and scan this flyer to view the AR content.

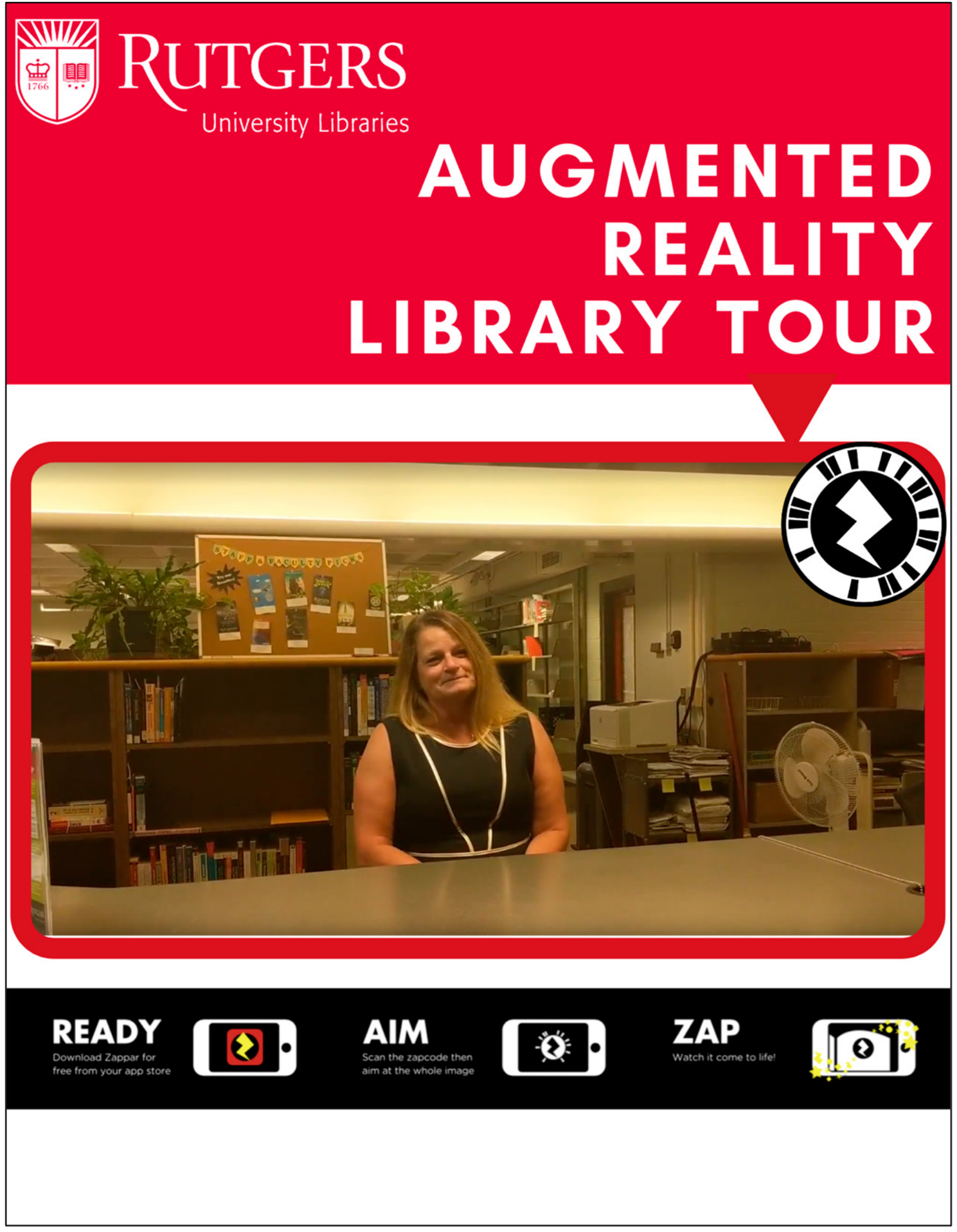




\section{APPENDIX C. Library Orientation: Student Pre-Orientation Questionnaire}

You are invited to take part in a research survey about the library orientation for the Rutgers University-Camden library. Your participation will require approximately 2 minutes and is completely voluntary. If you have questions about this survey, please contact [author] at [author's email].

Please provide your first and last initials (ex: SK):

Please answer the following questions about your prior experience with libraries.

On a scale of 1 to 4 , please rate how much you agree or disagree with the following statements.

\begin{tabular}{|l|c|c|c|c|}
\hline & $\begin{array}{c}\text { Strongly } \\
\text { Disagree } \\
1\end{array}$ & 2 & 3 & $\begin{array}{c}\text { Strongly } \\
\text { Agree } \\
4\end{array}$ \\
\hline $\begin{array}{l}\text { I am uncomfortable asking a librarian for } \\
\text { help. }\end{array}$ & 0 & 0 & 0 & 0 \\
\hline Libraries are welcoming places. & 0 & 0 & 0 & 0 \\
\hline Libraries overwhelm me. & 0 & 0 & 0 & 0 \\
\hline $\begin{array}{l}\text { The people who work in the library want to } \\
\text { help me. }\end{array}$ & 0 & 0 & 0 & 0 \\
\hline I know how to use academic libraries. & 0 & 0 & 0 & 0 \\
\hline
\end{tabular}




\section{APPENDIX D. Library Orientation: Student Post-Orientation Questionnaire}

You are invited to take part in a research survey about the library orientation for the Rutgers University-Camden library. Your participation will require approximately 5 minutes and is completely voluntary. If you have questions about this survey, please contact [author] at [author's email].

Please provide your first and last initials (ex: SK):

Please answer the following questions about libraries after taking the library orientation.

On a scale of 1 to 4 , please rate how much you agree or disagree with the following statements.

\begin{tabular}{|l|c|c|c|c|}
\hline & $\begin{array}{c}\text { Strongly } \\
\text { Disagree } \\
1\end{array}$ & 2 & 3 & $\begin{array}{c}\text { Strongly } \\
\text { Agree } \\
4\end{array}$ \\
\hline I am uncomfortable asking a librarian for help. & 0 & 0 & 0 & 0 \\
\hline Libraries are welcoming places. & 0 & 0 & 0 & 0 \\
\hline Libraries overwhelm me. & 0 & 0 & 0 & 0 \\
\hline $\begin{array}{l}\text { The people who work in the library want to help } \\
\text { me. }\end{array}$ & 0 & 0 & 0 & 0 \\
\hline I know how to use academic libraries. & 0 & 0 & 0 & 0 \\
\hline $\begin{array}{l}\text { I am uncertain where to ask for help at the Rutgers } \\
\text { University-Camden library. }\end{array}$ & 0 & 0 & 0 & 0 \\
\hline $\begin{array}{l}\text { I can easily find my way around the Rutgers } \\
\text { University-Camden library. }\end{array}$ & 0 & 0 & 0 & 0 \\
\hline I enjoyed this orientation experience. & 0 & 0 & 0 & 0 \\
\hline $\begin{array}{l}\text { I am eager to return to the Rutgers University- } \\
\text { Camden library. }\end{array}$ & 0 & 0 & 0 & 0 \\
\hline $\begin{array}{l}\text { I am likely to recommend the Rutgers University- } \\
\text { Camden library to other students. }\end{array}$ & 0 & 0 & 0 & 0 \\
\hline
\end{tabular}

\section{Notes}

1. Constance Mellon, "Library Anxiety: A Grounded Theory and Its Development," College and Research Libraries 47, no. 2 (March 1986): 163, https://doi.org/10.5860/crl_47_02_160.

2. Mellon, "Library Anxiety."

3. Sharon L. Bostick, "The Development and Validation of the Library Anxiety Scale" (PhD diss., Wayne State University, 1992).

4. Mellon, "Library Anxiety."

5. Tiffany Lemaistre, Qingmin Shi, and Sandip Thanki, "Connecting Library Use to Student Success," portal: Libraries and the Academy 18, no. 1 (January 2018): 117-40; Krista M. Soria, Jan Fransen, and Shane Nackerud, "Beyond Books: The Extended Academic Benefits of Library Use for First-Year College Students," College $\mathcal{E}$ Research Libraries 78, no. 1 (January 2017): 8-22; Karen Brown and Kara J. Malenfant, Academic Library Impact on Student Learning and Success: Findings from Assessment in Action Team Projects (Association of College and Research 
Libraries, 2017).

6. Marisa Alicia McPherson, "Library Anxiety among University Students: A Survey," IFLA Journal 41, no. 4 (December 2015): 317-25.

7. Qun G. Jiao, Anthony J. Onwuegbuzie, and Art A. Lichtenstein, "Library Anxiety: Characteristics of "Atrisk" College Students," Library \& Information Science Research 18, no. 2, 151-63; McPherson, "Library Anxiety among University Students."

8. Albert Bandura, "Self-Efficacy: Toward a Unifying Theory of Behavioral Change," Psychological Review 84, no. 2 (March 1977): 191-215.

9. Bandura, "Self-Efficacy."

10. Bandura, "Self-Efficacy."

11. Christy Teranishi Martinez, Ned Kock, and Jeffrey Cass, "Pain and Pleasure in Short Essay Writing: Factors Predicting University Students' Writing Anxiety and Writing Self-Efficacy: Through Mentoring and Tutoring, Teachers Can Help Students Become More Confident, Engaged Writers," Journal of Adolescent \& Adult Literacy 54, no. 5 (February 2011): 351-60; Lindy Woodrow, "College English Writing Affect: Self-Efficacy and Anxiety," System 39, no. 4 (December 2011): 510-22; Edgar Bresó, Wilmar Schaufeli, and Marisa Salanova, "Can a Self-Efficacy-Based Intervention Decrease Burnout, Increase Engagement, and Enhance Performance? A QuasiExperimental Study," Higher Education 61, no. 4 (April 2011): 339-55.

12. Michael Waldman, "Freshmen's Use of Library Electronic Resources and Self-efficacy," Information Research 8, no. 2 (January 2003); Wen-Hua Ren, "Library Instruction and College Student Self-Efficacy in Electronic Information Searching," Journal of Academic Librarianship 26, no. 5 (September 2000): 323-28.

13. Melissa Gross and Don Latham, "Attaining Information Literacy: An Investigation of the Relationship between Skill Level, Self-Estimates of Skill, and Library Anxiety," Library and Information Science Research 29, no. 3 (September 2007): 347.

14. Gross and Don Latham, "Attaining Information Literacy," 347.

15. Gross and Don Latham, "Attaining Information Literacy," 347.

16. Kristen A. Gilbert, Robert H. Voelkel, Jr., and Christie W. Johnson, "Increasing Self-Efficacy through Immersive Simulations: Leading Professional Learning Communities," Journal of Leadership Education 17, no. 3 (July 2018): 154-74.

17. Gilbert, Voelkel, and Johnson, "Increasing Self-Efficacy through Immersive Simulations," 154-74.

18. Mustafa Sirakaya and Ebru Kilic Cakmak, "Effects of Augmented Reality on Student Achievement and Self-Efficacy in Vocational Education and Training," International Journal for Research in Vocational Education and Training 5, no. 1 (April 2018): 1-18.

19. Sirakaya and Cakmak, "Effects of Augmented Reality on Student Achievement and Self-Efficacy in Vocational Education and Training," 13.

20. Sirakaya and Cakmak, "Effects of Augmented Reality on Student Achievement and Self-Efficacy in Vocational Education and Training"; Gilbert, Voelkel, and Johnson, "Increasing Self-Efficacy through Immersive Simulations."

21. Jorge Bacca et al., "Augmented Reality Trends in Education: A Systematic Review of Research and Applications," Journal of Educational Technology \& Society 17, no. 4 (October 2014): 133-49.

22. Cristina M. Botella et al., "In Vivo versus Augmented Reality Exposure in the Treatment of Small Animal Phobia: A Randomized Controlled Trial," PLoS ONE 11, no. 2 (2016): 1-22, https://doi.org/10.1371/journal. pone.0148237; Maja Wrzesien et al., "Treating Small Animal Phobias Using a Projective-Augmented Reality System: A Single-Case Study," Computers in Human Behavior 49, no. C (August 2015): 343-53; Cristina M. Botella et al., "Mixing Realities? An Application of Augmented Reality for the Treatment of Cockroach Phobia," CyberPsychology \& Behavior 8, no. 2 (April 2005): 162-71.

23. Tien-Chi Huang et al., "Get Lost in the Library?" Electronic Library 34, no. 1 (January 2016): 99-115, https:// doi.org/10.1108/EL-08-2014-0148.

24. Ashley Todd-Diaz, Arthur Gutierrez, and Bethanie O'Dell, “Using Augmented Reality to Enhance Outreach, Instruction, and Library Exhibits," Computers in Libraries 38, no. 1 (January/February 2018): 8-11.

25. Elizabeth Barnes and Robert M. Brammer, "Bringing Augmented Reality to the Academic Law Library," AALL Spectrum 17, no. 4 (February 2013): 13-31.

26. Chih-Ming Chen and Yen-Nung Tsai, "Interactive Augmented Reality System for Enhancing Library Instruction in Elementary Schools," Computers \& Education 59, no. 2 (September 2012): 651.

27. Kari Kozak, "Board 76: The Great Coffee Hunt: An Augmented Reality Scavenger Hunt," in ASEE Annual Conference \& Exposition (2019); Sarah LeMire et al., "Libr-AR-y Tours: Increasing Engagement and Scalability of Library Tours Using Augmented Reality," College \& Undergraduate Libraries 25, no. 3 (2018): 261-79; Jonathan Faustino Santos and Sharon Maria Esposo-Betan, "Advantages and Challenges of Using Augmented Reality for 
Library Orientations in an Academic/Research Library Setting," in Proceedings of the 38 Annual IATUL Conference, (2017).

28. Kozak, "Board 76"; Santos and Esposo-Betan, "Advantages and Challenges of Using Augmented Reality for Library Orientations in an Academic/Research Library Setting."

29. Amanda Roth et al., "Building a Scalable Mobile Library Orientation Activity with Edventure Builder," Library Hi Tech 34, no. 1 (March 2016): 36-44; Ann Goebel Brown et al., “Librarians Don't Bite: Assessing Library Orientation for Freshmen," Reference Services Review 32, no. 4 (December 2004): 394-403.

30. Sandra Marcus and Sheila Beck, "A Library Adventure: Comparing a Treasure Hunt with a Traditional Freshman Orientation Tour," College E Research Libraries 64, no. 1 (January 2003): 23-44.

31. Stacy Brinkman, Katie Gibson, and Jenny Presnell, "When the Helicopters Are Silent: The Information Seeking Strategies of First-Generation College Students," in Imagine, Innovate, Inspire: Proceedings of the ACRL 2013 Conference, ed. Dawn M. Mueller (Chicago, IL: ACRL, 2013), 647-48; Krista M. Soria, Shane Nackerud, and Kate Peterson, "Socioeconomic Indicators Associated with First-Year College Students' Use of Academic Libraries," Journal of Academic Librarianship 41, no. 5 (September 2015): 636-43.

32. Brinkman, Gibson, and Presnell, "When the Helicopters Are Silent."

33. Chris Marino, "Inquiry-based Archival Instruction: An Exploratory Study of Affective Impact," American Archivist 81, no. 2 (Fall/Winter 2018): 483-512.

34. Eugenie C. Regan and Keith R. Price, "The Frequency of Occurrence and Severity of Side-Effects of Immersion Virtual Reality," Aviation, Space, and Environmental Medicine 65, no. 6 (1994): 527-30; Eugenie C. Regan, "Some Evidence of Adaptation to Immersion in Virtual Reality," Displays 16, no. 3 (July 1995): 135-39; Sarah Sharples et al., "Virtual Reality Induced Symptoms and Effects (VRISE): Comparison of Head Mounted Display (HMD), Desktop and Projection Display Systems," Displays 29, no. 2 (March 2008): 58-69; David Drascic and Paul Milgram, "Perceptual Issues in Augmented Reality," in Proceedings of SPIE: The International Society for Optical Engineering, 2653 (1996): 123-34.

35. Melanie C. Hibbert, Alexis Seeley, and Abby Lee, "Dance Magic Dance: A Case Study of AR/360 Video and the Performing Arts," in Augmented and Virtual Reality in Libraries, eds. Jolanda-Pieta Van Arnhem, Christine Elliott, and Marie Rose (Lanham, MD: Rowman \& Littlefield, 2018), 129-41; Bethanie O'Dell and Art Gutierrez, "'Blipping' Through Information Literacy: Using the Blippar App in Instruction," in Augmented and Virtual Reality in Libraries, eds. Jolanda-Pieta Van Arnhem, Christine Elliott, and Marie Rose (Lanham, MD: Rowman \& Littlefield, 2018), 113-25.

36. Bandura, "Self-Efficacy," 202. 